\title{
Establishment of a New Fish Cell Line from the Brain of 1 Humpback Grouper (Chromileptes Altivelis), and its Application in Toxicology and Bacterial Susceptibility
}

\section{Yixuan Liu \\ Hainan University \\ Caoying Wei \\ Hainan University \\ Zhiru Liu \\ Hainan University \\ Zhenjie Cao \\ Hainan University}

Yun Sun ( $\nabla$ syshui207@126.com )

Hainan University https://orcid.org/0000-0002-5805-7208

Yongcan Zhou

Hainan University

Shifeng Wang

Hainan University

Weiliang Guo

Hainan University

\section{Research Article}

Keywords: Chromileptes altivelis, Brain cell line, Transfection efficiency, Toxic effect, Bacterial susceptibility

Posted Date: June 18th, 2021

DOI: https://doi.org/10.21203/rs.3.rs-612916/v1

License: (c) (1) This work is licensed under a Creative Commons Attribution 4.0 International License.

Read Full License 

8

9 10 and its application in toxicology and bacterial susceptibility

Yixuan Liu ${ }^{\mathrm{a}, \mathrm{b}, 1}$, Caoying Wei ${ }^{\mathrm{a}, \mathrm{b}, 1}$, Zhiru Liu, ${ }^{\mathrm{a}, \mathrm{c}}$, Zhenjie Cao ${ }^{\mathrm{a}, \mathrm{b}, *}$, Yun Sun ${ }^{\mathrm{a}, \mathrm{b}, *}$, Yongcan Zhou ${ }^{\mathrm{a}, \mathrm{b}}$, Shifeng Wang $^{\mathrm{a}, \mathrm{b}}$, Weiliang Guo ${ }^{\mathrm{b}}$

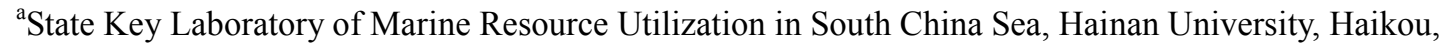
Hainan 570228, PR China

${ }^{\mathrm{b}}$ Key Laboratory of Tropical Hydrobiology and Biotechnology of Hainan Province, Haikou, Hainan 570228, PR China

${ }^{\mathrm{c}}$ Department of Aquaculture, College of Marine Sciences, Hainan University, Haikou, Hainan 570228, PR China

11

${ }^{1}$ These authors contributed equally to this work.

* To whom correspondence should be addressed.

Mailing address:

College of Marine Sciences
Hainan University
58 Renmin Avenue
Haikou 570228
PR ChinaPhone and Fax: 86-898-66256125
Email: czj203@126.com;
syshui207@126.com

running head: A NEW CELL LINE FROM CROMILEPTES ALTIVELIS 


\section{Abstract}

Cromileptes altivelis, humpback grouper, belongs to the family Epinephelidae and is one popular farmed fish species because of its high economic value and ornamental value. However, more and more diseases were outbreak with the increasing of $C$. altivelis breeding, resulting in severe economic losses. Today, a new brain cell line of $C$. altivelis $(\mathrm{CAB})$ was established and has been subcultured for more than 40 passages until now. Our results showed that the morphology of $\mathrm{CAB}$ cells is epithelial-like and suitable for growth at $26{ }^{\circ} \mathrm{C}$ in $\mathrm{L} 15$ medium supplemented with $15 \%$ fetal bovine serum (FBS). The results of $18 \mathrm{~S}$ rRNA gene sequencing confirmed that CAB cell line was derived from C. altivelis. Moreover, $\mathrm{CAB}$ cells were apparently diploid number of chromosomes $(2 n=48)$ by chromosome analysis. In addition, $\mathrm{CAB}$ cells could transfect pEGFP-N3 plasmid with high transfection efficiency, indicating that $\mathrm{CAB}$ cell line has the potential to investigate the function of exogenous genes in vitro. Furthermore, the bacterial susceptibility results suggested that $\mathrm{CAB}$ cells were susceptive to Vibrio harveyi and Edwardsiella tarda. And, heavy metals $(\mathrm{Hg}, \mathrm{Cd}$, and $\mathrm{Cu})$ were toxic to the $\mathrm{CAB}$ cells and the toxic effect was dose-dependent. In summary, the CAB cell line could be a powerful tool in vitro to study functional genes and has the potential application in bacterial susceptibility and toxicology.

Keywords: Chromileptes altivelis $\cdot$ Brain cell line $\cdot$ Transfection efficiency $\cdot$ Toxic effect $\cdot$ Bacterial susceptibility 


\section{Introduction}

Cromileptes altivelis (belongs to Serranidae, Epinephelinae, Cromileptes) is mainly distributed in subtropical waters in the South Sea of China (Zhang et al., 2020). As the breeding density of $C$. altivelis increases, diseases are occurring with increasing frequency (Sun et al., 2019). While at the same time, slow growth and low survival rate in the wild greatly limited the amount of C. altivelis, which leads to the listing of $C$. altivelis as an endangered species (Afero et al., 2010; Suprayudi et al., 2016; Wei et al., 2018). Fish cell lines is an important material and model for germplasm preservation, gene function analysis and cell engineering breeding, immunology, endocrinology, and functional genomics (Laing et al., 2011; Skrzypski et al., 2016; Zhou et al., 2019). Consequently, establishment of cell lines derived from the endangered C. altivelis is of great significance.

Previous studies have shown that diseases caused by bacteria have brought serious damages to aquaculture (Li et al., 2016; Gong et al., 2018). Excitedly, fish cell lines are the convenient tool in monitoring the adverse effect of bacteria (Rachlin et al., 1968). For example, brain cell line of Trachinotus ovatus (TOGB) was highly sensitive to virus (grouper nervous necrosis virus (GNNV) and singapore grouper iridovirus (SGIV)) and bacteria (Vibrio anguillarum and V. alginolyticus) (Li et al., 2016). As far as we know, V. harveyi and Edwardsiella tarda are two kinds of usual pathogenic bacteria which widely infected many marine and freshwater fish species (Takano et al., 2010; Liu et al., 2016). With the aforementioned issue, there is an urgent need to construct cell lines from $C$. altivelis as an effective tool for monitoring the adverse effect of $V$. harveyi and E. tarda.

Besides bacteria, heavy metals are common environmental pollutants, which present extremely cytotoxic to living body and bring a health threat to people (Sapkota et al., 2008; Gong et al., 2018; Renieri et al., 2019). Fish cell cultures also can be applied to detect the environmental pollutant 
chemicals as a sensitive biological monitoring system (Segner et al., 2004; Tan et al., 2008; Zhou et al., 2017). Previous study suggested that ovary cell line of Ictalurus punctatus and kidney cell line of Ctenopharyngodon idella were sensitive to cadmium $(\mathrm{Cd})$ and copper $(\mathrm{Cu})$, respectively, and could indicate the acute cytotoxicity of heavy metals in the aquatic environment (Tan et al., 2008). However, different fish cell lines demonstrated varying degrees of sensitivity to different heavy metals. Thus, establishment of various fish cell lines is essential for detecting the sensitive to heavy metals.

To address this, a new brain cell line from $C$. altivelis (CAB) was established and characterized. Moreover, the application possibility in foreign gene expression of $\mathrm{CAB}$ cells was assessed. Besides, the sensitivities of $\mathrm{CAB}$ cells to $V$. harveyi, E. tarda, and three heavy metals $(\mathrm{Cu}, \mathrm{Hg}$, and $\mathrm{Cd})$ have been evaluated. Our study will enrich the resources of fish cell lines, and provides important experimental materials for future research on the prevention and control technology of fish diseases.

\section{Materials and methods}

\section{Isolation and cultured of primary brain cells}

C. altivelis (approximately $10 \mathrm{~cm}$ in length) were obtained from a seafood market in Haikou (Hainan, China). Prior to primary cell culture, fish were soaked in 1\% iodophor for 15 minutes. Then the skin of the fish was wiped with $75 \%$ ethanol to be sterilized. Brain was taken out aseptically and washed three times with Leibovitz's L-15 medium (Gibco) containing 4\% antibiotics (400 $\mu \mathrm{g} / \mathrm{ml}$ streptomycin, $400 \mathrm{IU} / \mathrm{ml}$ penicillin). After that, it had been digested for 30 min with $1 \mathrm{ml} 0.25 \%$ trypsin solution (Gibco). Next, the digested mixture was percolated using a 100 mesh screen, and the filtrate was centrifuged at $180 \mathrm{~g}$ for $10 \mathrm{~min}$ to collect the precipitate. The precipitate was then cultured in $3 \mathrm{ml}$ L-15 medium that containing $20 \%$ fetal bovine serum (FBS, Gibco), $20 \mathrm{ng} / \mathrm{ml}$ basic fibroblast growth 
factor (bFGF, Peprotech), $40 \mathrm{ng} / \mathrm{ml}$ insulin-like growth factor-I (IGF-I, Peprotech), and $4 \%$ antibiotics at $26{ }^{\circ} \mathrm{C}$ in $25 \mathrm{~cm}^{2}$ cell culture flasks. In daily administration, medium was refreshed every three days until the cells reached at a high confluence $(>85 \%)$.

\section{Subculture, cryopreservation and recovery of cell}

The primary cells that formed an intact monolayer were detached from the flasks surface with $0.25 \%$ trypsin solution for subculture with the rate of $1: 2$. After more than 20 times of subculture, the content of FBS in L-15 medium was steadily changed from $20 \%$ to $15 \%$ FBS, and no longer required the bFGF and IGF-I.

For long-term storage, $\mathrm{CAB}$ cells after initial 5 passages were digested with $0.25 \%$ trypsin-EDTA solution. Then the compound was centrifuged at $1000 \mathrm{~g}$ for $5 \mathrm{~min}$ and resuspended in L-15 medium for eliminating EDTA. After centrifugation 2 times, cells were resuspended in cell freezing medium that contains $40 \%$ FBS and 10\% dimethyl sulfoxide in L-15 medium. The cells in cryogenic vials were stored at $-80{ }^{\circ} \mathrm{C}$ overnight and removed into the liquid nitrogen next day. Resuscitation test was performed as follows: $\mathrm{CAB}$ cells that stored in liquid nitrogen were taken out quickly and put it into a $37^{\circ} \mathrm{C}$ water bath immediately for $80 \mathrm{~s}$. Afterwards, cells were added into $25 \mathrm{~cm}^{2}$ flasks with $4 \mathrm{ml} \mathrm{L}-15$ medium to culture. Finally, trypan blue test was conducted to analyze the cell viability as described by our previous study (Wang et al., 2020).

\section{S rRNA gene analysis}

The genomic DNA of CAB cells at passage 10 was isolated by Tissue DNA kit (Omega Bio-tek, USA). The 18S rRNA was amplified with the following primers: Forward, 
Afterwards, the obtained PCR product was determined by agarose gel and sequenced.

\section{Optimal growth conditions}

The effect of different mediums (L15, DMEM, MEM, M199), culture temperatures $\left(22{ }^{\circ} \mathrm{C}, 24^{\circ} \mathrm{C}\right.$, three times.

\section{Chromosome analysis}

Cells at passage 7 were used for chromosome analysis. Briefly, cells were cultured until a complete monolayer appeared. Then, cells were treated with $0.6 \mu \mathrm{g} / \mathrm{ml}$ of colchicine (Sigma-Aldrich) for $6 \mathrm{~h}$. After that, cells were digested using trypsin and collected by centrifugation at $800 \mathrm{~g}$ for $10 \mathrm{~min}$. $8 \mathrm{ml}$ of $\mathrm{KCl}$ solution $(0.075 \mathrm{M})$ were supplemented to resuspend cells at $26^{\circ} \mathrm{C}$ for $30 \mathrm{~min}$. Afterwards, the suspended mixture were incubated with $2 \mathrm{ml}$ of precooled Carnoy's fixative (methanol : acetic acid $=3: 1$ ) at room temperature for $5 \mathrm{~min}$. Then, after centrifugation for $10 \mathrm{~min}$ at $600 \mathrm{~g}$, cells were microscope. 
As previously mentioned, the cell cycle of $\mathrm{CAB}$ cells at passage 20 was analyzed using flow cytometry (Wang et al., 2020). Firstly, CAB cells were seeded and digested using trypsin after cultured for $24 \mathrm{~h}$ and $48 \mathrm{~h}$, respectively. Then, cells were collected and washed with pre-cooled PBS. Following that, $70 \%$ pre-cooled ethanol was added into the collected cells and stored at $4{ }^{\circ} \mathrm{C}$ overnight. Then, cells were centrifuged at $1000 \mathrm{~g}$ for $5 \mathrm{~min}$ at $4{ }^{\circ} \mathrm{C}$ and the sediments were resuspended with pre-cooled PBS. After centrifugation again, sediments were incubated in PI staining fluid (Beyotime, China) for 30 min at $37^{\circ} \mathrm{C}$. The fluorescence signal was detected by a Guava easyCyte (Luminex Corporation, USA). The data were analyzed by Modfit LT (Verity Software House, USA).

\section{Cell transfection}

To evaluate the transfection efficiency and detect whether foreign genes can express successfully in $\mathrm{CAB}$ cell lines, $2 \mu \mathrm{g}$ of the pEGFP-N3 plasmid expressed green fluorescent protein (GFP) was transfected into $\mathrm{CAB}$ cells at passage 12 using FuGene ${ }^{\circledR} 6$ Transfection Reagent (Promega, USA) according to the specification. $72 \mathrm{~h}$ after transfection, the cells expressed GFP were counted through an inverted fluorescence microscope (Leica, Germany) and the transfection efficiency was expressed as the following formula: Transfection efficiency $(\%)=$ (numbers of GFP-positive cells independent light fields / numbers of total cells in 20 independent light fields) $\times 100$.

\section{Bacterial susceptibility assays}

To evaluate the susceptibility of $V$. harveyi and E. tarda on $\mathrm{CAB}$ cells, the $\mathrm{CAB}$ cells were cultured in a 6-well plate at $26{ }^{\circ} \mathrm{C}$ until a complete monolayer appeared. $V$. harveyi and E. tarda with the concentration of $1 \times 10^{5} \mathrm{CFU} /$ well were supplemented into the 6-well plate and co-incubated with 
161

cells at $26{ }^{\circ} \mathrm{C}$, respectively. As a control, same volume of PBS was added into the well. After incubation for $1 \mathrm{~h}$ and $3 \mathrm{~h}$, the susceptibility of $V$. harveyi on CAB cells was observed using inverted fluorescence microscope (Leica, Germany). Meanwhile, the susceptibility of E. tarda on CAB cells was evaluated after infection for $6 \mathrm{~h}$ and $9 \mathrm{~h}$.

\section{Cytotoxic effect of heavy metals}

To assess the toxic effects of heavy metals on $\mathrm{CAB}$ cells, CAB cells were cultured until a complete monolayer appeared in a 96-well plate. Three kinds of heavy metals (copper chloride $\left(\mathrm{CuCl}_{2}\right)$, mercury chloride $\left(\mathrm{HgCl}_{2}\right)$, and cadmium chloride $\left(\mathrm{CdCl}_{2}\right)$ ) were diluted by medium to $0.0001,0.001$, $0.01,0.1,1$, and $10 \mathrm{mM}$, respectively. Then, heavy metals above were supplemented into the 96-well plate and co-incubated with cells at $26^{\circ} \mathrm{C}$, respectively. As a control, same volume of medium was supplemented into the cells. The viability of cells was evaluated by CCK-8 kit (Bosharp, USA).

\section{Statistical analysis}

Data in this study were calculated by SPSS 17.0 software (IBMSPSS. Inc., USA) and presented in the way of means \pm SD. The significant part was performed through One-way ANOVA analysis. The statistically significant was marked when $\mathrm{P}$ value $<0.05$.

\section{Results}

\section{Primary cell culture and subculture}

As shown in Fig. 1, the formed confluent monolayer of the primary cells was occurred at 16 days of incubation. After that, cells were subcultured at a proportion of 1:2 or 1:3 every 4 days. Up to now, the $\mathrm{CAB}$ cells have been subcultured more than 40 passages. When cryopreserved cells were revived 
for $24 \mathrm{~h}$, a part of cells adhered successfully (Fig. 2a), and the cell morphology was the same as before cryopreservation (Fig. 2b).

\section{Molecular characterization of $\mathrm{CAB}$ cells line}

PCR identification of CAB cell $18 \mathrm{~S}$ rRNA gene showed that there was a single band at $1800 \mathrm{bp}$ approximately, which is the expected length (Fig. 3a). The sequencing results were aligned on the NCBI website and results showed that the sequence was $100 \%$ homologous to the C. altivelis $18 \mathrm{~S}$ rRNA gene sequence (NCBI Accession No. MZ298593), suggesting that CAB cell line was indeed originated from C. altivelis.

\section{Optimum culture condition}

The effect of various mediums, culture temperatures and concentrations of FBS on CAB cells were evaluated. The results showed that $\mathrm{CAB}$ cells grow the fastest in L15, while in the MEM or DMEM medium, CAB cells couldn't proliferate normally (Fig. 4a). When CAB cells were cultured in L15 medium containing different FBS concentrations, we found that the growth rates of CAB cells in $15 \%$ and $20 \%$ FBS were significantly increased than that in $10 \%$ and $5 \%$ FBS, while there was no significant difference between $15 \%$ and $20 \%$ FBS (Fig. 4b). Considering the costs, 15\% was the optimum concentration of FBS for $\mathrm{CAB}$ cells cultured. The study of the optimum temperature for CAB cells cultured exhibited that $\mathrm{CAB}$ cells could grow at $22{ }^{\circ} \mathrm{C}, 24{ }^{\circ} \mathrm{C}, 26{ }^{\circ} \mathrm{C}$, and $28^{\circ} \mathrm{C}$ and its optimum temperature was $26^{\circ} \mathrm{C}$ (Fig. 4c).

\section{Cell chromosome analysis}



have 48 chromosomes $(2 \mathrm{~N}=48)$ (Fig. 5).

\section{Cell cycle analysis}

The DNA contents of CAB cell lines analyzed by flow cytometric after cultured for $24 \mathrm{~h}$ and $48 \mathrm{~h}$ were shown in Fig. 6. The results showed that both of two visible peaks (the G0-G1 period and G2-M period) were occurred in cells cultured for $24 \mathrm{~h}$ and $48 \mathrm{~h}$, respectively. Moreover, cells at G0-G1 phase $(82.90 \%)$ and G2-M phase (4.82\%) after cultured for $48 \mathrm{~h}$ were more than that cultured for $24 \mathrm{~h}$ (69.13\% and 3.34\%), respectively (Fig. 6c). By contrast, the percent of cells at S period after cultured for $24 \mathrm{~h}(27.54 \%)$ were higher than that cultured for $48 \mathrm{~h}$ (12.28\%) (Fig. 6c).

\section{Transfection efficiency} pEGFP-N3 plasmid for $72 \mathrm{~h}$. According to the formula of transfection efficiency, the cell transfection efficiency was approximately $25 \%$ (Fig. 7). control group was normal. 


\section{Heavy metal cytotoxicity assays for CAB cells}

A dose-dependent manner was found in the heavy metal cytotoxicity assays for CAB cells. That is, the higher the concentration of all the three kinds of heavy metal $(\mathrm{Cd}, \mathrm{Cu}$, and $\mathrm{Hg})$, the lower the viability of $\mathrm{CAB}$ cells (Fig. 9). The results indicated that $\mathrm{Cd}, \mathrm{Cu}$, and $\mathrm{Hg}$ were toxic to $\mathrm{CAB}$ cells.

When the concentration of $\mathrm{Hg}$ and $\mathrm{Cu}$ was decreased to $0.001 \mathrm{mM}$, the viability of $\mathrm{CAB}$ cells assumed a remarkable reduction. Meanwhile, the concentration of $\mathrm{Hg}$ was increased to $10 \mathrm{mM}$, the livability of $\mathrm{CAB}$ cells was reduced to approximately $27 \%$. By contract, the cytotoxicity of $\mathrm{Cd}$ for $\mathrm{CAB}$ cells was detectable at the concentration of $0.01 \mathrm{mM}$. As a result, the calculated IC50 of $\mathrm{Hg}$ and $\mathrm{Cd}$ was 0.393 $\mathrm{mM}$ and $0.445 \mathrm{mM}$, respectively, while the IC50 of $\mathrm{Cu}$ was $1.073 \mathrm{mM}$.

\section{Discussion}

market development was bothered by the slow growth and frequent diseases (Sun et al., 2019). The development of fish cell lines provides new experimental materials and ideas for the research of bacteria and the impact of environmental heavy metals on fish. Epinephelus coioides, Epinephelus akaara, T. ovatus and Sparus aurata (Wen et al., 2008; Li et al., 
containing $15 \% \mathrm{FBS}$ at $26^{\circ} \mathrm{C}$. Correspondingly, Zhang et al (2014) reported that C. altivelis could grow well when the water temperature was between 24 and $32{ }^{\circ} \mathrm{C}$ (Wang et al., 2013; Zhang et al., 2014). Ou and Xie (2007) reported that the modal number of diploid chromosome in C. altivelis was 48. Correspondingly, the modal chromosome number of CAB cell line is 48 . Continuous culturable cell lines are quite imperative in cytogenetic analysis (Wang et al., 2010; Yu et al., 2016). In our study, the analysis of cell cycle by flow cytometric showed that the CAB cells cultured for $48 \mathrm{~h}$ possessed a lower percentage of cells in the S phase compared to $24 \mathrm{~h}$, indicating that the $\mathrm{CAB}$ cells comprised a diploid cell population that had a firm ability for continuous culture. Similar results were found in the heart cell lines from Epinephelus lanceolatus (ELGH) and the snout cell lines from $T$. ovatus (GPS) (Guo et al., 2015; Yu et al., 2016). Up to now, CAB cells had been subcultured for more than 40 passages. Given all this, the brain cell line from $C$. altivelis that could be passaged stably had been established successfully by us.

High transfection efficiency is an essential index when evaluated whether cell lines can be applied in foreign gene expression (Qin et al., 2006; Zheng et al., 2012; Zhang et al., 2014; Yu et al., 2016). In this study, the transfection efficiency of CAB cells transfected with the pEGFP-N3 plasmid was nearly 25\%, which was similar with the kidney cell line from Cynoglossus semilaevis (Lou et al., 2020), and higher than the Lateolabrax japonicus pluripotent embryonic cell line (Chen et al., 2003), demonstrating that the $\mathrm{CAB}$ cell line can be used in the study of foreign gene expression.

Previous studies indicated that fish cell lines have the clear advantages to predict the acute fish toxicity (Fent., 2001; Huang et al., 2011). More than that, they are effective tools to explore the cytotoxicity of pathogenic bacteria (Qin et al., 2006; Huang et al., 2011; Yu et al., 2016; Wei et al., 2018). For example, Streptococcus iniae and V. alginolyticus showed strong cytotoxic to the heart 
cell line of E. lanceolatus (Huang et al., 2011). As we know, V. harveyi and E. tarda can infect a variety of aquaculture species and cause serious financial losses, especially $V$. harveyi (Li et al., 2011; Liu et al., 2016; Tu et al., 2017). In this study, V. harveyi and E. tarda showed severe cytotoxicity to $\mathrm{CAB}$ cells. Moreover, the cytotoxicity of $V$. harveyi to $\mathrm{CAB}$ cells was stronger than that of $E$. tarda. Consistent with those of results in vitro, $V$. harveyi could cause acute pathogenicity to $C$. altivelis in vivo as previously described (Sun et al., 2019). Thus, CAB cell line has the potential utility in detecting cytotoxicity of the bacterial pathogens.

To date, heavy metal pollution has become one of the main environmental problems and has caused great harm to environment, aquatic animals, and even human health (Gong et al., 2018). Numerous studies have shown that fish cell lines are effective tools to monitor heavy metal pollution for early warning of their toxicity in the aquatic environment (Gülden et al., 2005; Liu et al., 2017). Previous studies showed that each fish cell line has a great different sensitivity in response to toxicants. It is necessary to detect the toxicity of different heavy metal to different cell lines, so as to establish a sensitive and suitable in vitro cell model for the study of early warning of heavy metal toxicity. In this study, the toxicity of three heavy metals $(\mathrm{Cd}, \mathrm{Hg}$ and $\mathrm{Cu})$ on $\mathrm{CAB}$ cells was detected and showed a dose-dependent manner. Results indicated that $\mathrm{CAB}$ cells were more sensitive to $\mathrm{Hg}$ than $\mathrm{Cd}$ and $\mathrm{Cu}$. The similar results were also found in fibroblast SAF-1 cell line from S. aurata L. and muscle cell line from C. altivelis (Morcillo et al., 2016; Wang et al., 2020). The IC50 showed that the cytotoxicity of $\mathrm{Hg}(0.393 \mathrm{mM})$ was more remarkable than that of $\mathrm{Cd}(0.445 \mathrm{mM})$ and $\mathrm{Cu}(1.073 \mathrm{mM})$ in $\mathrm{CAB}$ cells. Similarly, in mid-kindey cell line from $T$. ovatus, $\mathrm{Hg}$ showed higher toxicity than that of $\mathrm{Cd}$ and $\mathrm{Cu}$ (Zhou et al., 2017). All these data consistently revealed that CAB cell line could be used for monitoring heavy metal pollution. 


\section{Conclusions}

In conclusion, our study established a $C$. altivelis brain cell line. The CAB cell line has good

299

\section{Author Declarations} Editing harveyi and E. tarda, as well as three heavy metals $(\mathrm{Hg}, \mathrm{Cd}$, and $\mathrm{Cu})$, indicating that $\mathrm{CAB}$ cell line has the potential application in exploring the effect of pathogenic bacteria and heavy metals on host.

Funding This research was supported financially by the Special Project on Blue Granary Science and Technology Innovation under the National Key R \& D Program (2020YFD0901103) and Natural Science Foundation of Hainan Province (320QN212).

Conflict of interest The authors declare that they have no conflict of interest.

Ethics approval Animal care was performed conformity with NIH guidelines (NIH Pub. No. 85e23, revised 1996) and was approved by Animal Care and Use Committee of the Hainan University.

Consent to participate Participate consent has been received from all authors.

Consent for publication Permission has been obtained from all authors for this article.

Data availability The study has the data and material.

Authors' contributions Yixuan Liu: Formal analysis, Writing- Original draft preparation; Caoying Wei: Formal analysis, Data Curation, Software, Visualization; Zhiru Liu: Project administration; Zhenjie Cao: Conceptualization, Methodology, Writing- Reviewing and Editing; Yun Sun: Supervision, Writing- Reviewing and Editing; Yongcan Zhou: Data Curation; Shifeng Wang: 


\section{References}

Afero F, Miao S, Perez AA (2010) Economic analysis of tiger grouper Epinephelus fuscoguttatus and humpback grouper Cromileptes altivelis commercial cage culture in Indonesia. Aquacult Int 18:725-739. https://doi.org/10.1007/s10499-009-9295-X

Chen SL, Sha ZX, Ye HQ (2003) Establishment of a pluripobtent embryonic cell line from sea perch (Lateolabrax japonicus) embryos. Aquaculture 218(1-4):141-151. https://doi.org/10.1016/S0044-8486(02)00570-7

Fent K (2001) Fish cell lines as versatile tools in ecotoxicology: assessment of cytotoxicity, cytochrome P4501A induction potential and estrogenic activity of chemicals and environmental samples. Toxicol in Vitro 15:477-488. https://doi.org/10.1016/s0887-2333(01)00053-4

Guo CY, Huang YH, Wei SN, Ouyang ZL, Yan Y, Huang XH, Qin Q (2015) Establishment of a new cell line from the heart of giant grouper, Epinephelus lanceolatus (B loch), and its application in toxicology and virus susceptibility. J Fish Dis 38(2):175-186. https://doi.org/10.1111/jfd.12221

Gong HM, Liu Y, Xiao YY, Li CH (2018) Assessment on heavy metals pollution and potential ecological risk of seawater and surface sediments in coastal waters: A case study in Xincun lagoon. Res Agricultural Modernization 39:700-708. https://doi.org/10.13872/j.1000-0275.2018.0039

Gravell M, Malsberger RG (1965) A permanent cell line from the fathead minnow (Pimephales promelas). Ann Ny Acad Sci 126(1): 555-565. https://doi.org/10.1111/j.1749-6632.1965.tb14302.x

Gülden M, Mörchel S, Seibert H (2005) Comparison of mammalian and fish cell line cytotoxicity: impact of endpoint and exposure duration. Aquat Toxicol 71:229-236. https://doi.org/10.1016/j.aquatox.2004.11.006

Huang XH, Huang YH, Sun JJ, Han X, Qin QW (2009) Characterization of two grouper Epinephelus akaara cell lines: Application to studies of Singapore grouper iridovirus (SGIV) propagation and $\begin{array}{lll}\text { virus-host interaction. } & \text { Aquaculture } & \text { 292(3):172-179. }\end{array}$ https://doi.org/10.1016/j.aquaculture.2009.04.019

Huang XH, Huang YH, Ouyang ZL, Qin QW (2011) Establishment of a cell line from the brain of grouper (Epinephelus akaara) for cytotoxicity testing and virus pathogenesis. Aquaculture 311:65-73. https://doi.org/10.1016/j.aquaculture.2010.11.037

Li MF, Wang CL, Sun L (2011) A pathogenic Vibrio harveyi lineage causes recurrent disease outbreaks in cultured Japanese flounder (Paralichthys olivaceus) and induces apoptosis in host cells. Aquaculture 319:30-36. https://doi.org/10.1016/j.aquaculture.2011.06.034

Li P, Zhou L, Wei S, Yang M, Ni S, Yu Y, Cai J, Qin Q (2017) Establishment and characterization of a cell line from the head kidney of golden pompano, Trachinotus ovatus and its application in toxicology and virus susceptibility. J Fish Biol 90:1944-1959. https://doi.org/10.1111/jfb.13277

Li PF, Zhou LL, Ni SW, Xu M, Yu YP, Cai J, Wei SN, Qin QW (2016) Establishment and characterization of a novel cell line from the brain of golden pompano (Trachinotus ovatus). In Vitro Cell Dev-An 52:410-418. https://doi.org/10.1007/s11626-015-9988-6

Liu L, Ge MF, Zheng XY, Tao Z, Zhou SM, Wang GL (2016) Investigation of Vibrio alginolyticus, $V$. harveyi, and $V$. parahaemolyticus in large yellow croaker, Pseudosciaena crocea, (Richardson) reared in Xiangshan Bay, China. Aquacult Rep 3:220-224. https://doi.org/10.1016/j.aqrep.2016.04.004 
Liu CF, Li B, Wang YT, Liu Y, Cai HJ, Wei HF, Wu JW, Li J (2017) Comprehensive risk assessment and source identify cation of selected heavy metals $(\mathrm{Cu}, \mathrm{Cd}, \mathrm{Pb}, \mathrm{Zn}, \mathrm{Hg}, \mathrm{As})$ in tidal saltmarsh sediments of Shuangtai Estuary, China. Environ Monit Assess 189:541. https://doi.org/10.1007/s10661-017-6245-3

Laing KJ, Hansen JD (2011) Fish T cells: Recent advances through genomics. Dev Comp Immunol 35(12): 1282-1295. https://doi.org/10.1016/ j.dci.2011.03.004

Lou Y N, Sun B, Zhang L N, Li Y, Xiao P (2020) Establishment and characterization of a new cell line derived from half-smooth tongue sole Cynoglossus semilaevis kidney. J Oceanol Limnol 38(02): 560-570. https://doi.org/10.1007/s00343-019-9084-y

María R, M.Ángeles E, Alberto C (2020) Establishment of a brain cell line (SaB-1) from gilthead seabream and its application to fish virology. Fish Shellfish Immunol 106:161-166. https://doi.org/10.1016/j.fsi.2020.07.065

Morcillo P, Esteban MÁ, Cuesta A (2016) Heavy metals produce toxicity, oxidative stress and apoptosis in the marine teleost fish SAF-1 cell line. Chemosphere 144:225-233. https://doi. org/10.1016/j.chemosphere.2015.08.020

Peng LM, Zheng Y, You F, Wu ZH, Zou YX, Zhang PJ (2016) Establishment and characterization of a testicular Sertoli cell line from olive flounder Paralichthys olivaceus. Chin J Oceanol Limn 34(5):1054-1063. https://doi.org/10.1007/s00343-016-5091-4

Qin QW, Wu TH, Jia TL, Hegde A, Zhang RQ (2006) Development and characterization of a new tropical marine fish cell line from grouper, Epinephelus coioides susceptible to iridovirus and nodavirus. J Virol Methods 131:58-64. https://doi.org/10.1016/j.jviromet.2005.07.009

Qu YJ, Xie J (2007) Karyotype analysis of Cromileptes altivelis. South China Fisheries Science $3: 49-53$.

Rachlin JW, Perlmutter A (1968) Fish cells in culture for study of aquatic toxicants. Water Res 2:409-414. https://doi. org/10.1016/0043-1354(68)90060-2

Renieri EA, Safenkova IV, Alegakis AK, Slutskaya ES, Kokaraki V, Kentouri M, Dzantiev BB, Tsatsakis AM (2019) Cadmium, lead and mercury in muscle tissue of gilthead seabream and seabass: risk evaluation for consumers. Food Chem Toxicol 124:439-449. https://doi.org/10.1016/j. fct.2018.12.020

Sapkota A, Sapkota AR, Kucharski M, Burke J, McKenzie S, Walker P, Lawrence R (2008) Aquaculture practices and potential human health risks: current knowledge and future priorities. Environ Int 34:1215-1226. https://doi.org/10.1016/j.envint.2008.04.009

Segner H (2004) Cytotoxicity assays with fish cells as an alternative to the acute lethality test with fish. Atla-Altern Lab Anim 32:375-382. https://doi.org/10.1080/08934210802305028

Sun Y, Xiang YJ, He MW, Zhang X, Wang SF, Guo WL, Liu CS, Cao ZJ, Zhou YC (2019) Evaluation of Lactococcus lactis HNL12 combined with Schizochytrium limacinum algal meal in diets for humpback grouper (Cromileptes altivelis). Fish Shellfish Immunol 94:880-888. https://doi.org/10.1016/j.fsi.2019.09.059

Suprayudi MA, Hajiali F, Utomo NBP, Ekasari J, Fauzi I (2016) Evaluation of smoked skipjack processing byproduct meal as an alternative feed ingredient for juvenile humpback grouper $\begin{array}{llll}\text { Cromileptes } \quad \text { altivelis. } & \text { HAYATI }\end{array}$ http://dx.doi.org/10.1016/j.hjb.2015.08.002

Skrzypski M, Khajavi N, Mergler S, Szczepankiewicz D, Wojciechowicz T, Nowak KW, Strowski MZ (2016) Orexin A modulates INS-1E cell proliferation and insulin secretion via extracellular 
signal-regulated kinase and transient receptor potential channels. J Physiol Pharmacol, 67(5): 643-652. https://pubmed.ncbi.nlm.nih.gov/28011945/

Takano T, Matsuyama T, Oseko N, Sakai T, Kamaishi T, Nakayasu C, Sano M, Iida T (2010) The efficacy of five avirulent Edwardsiella tarda strains in a live vaccine against Edwardsiellosis in Japanese flounder, Paralichthys olivaceus. Fish Shellfish Immunol 29:687-693. https://doi.org/10.1016/j.fsi.2010.07.012

Tan FX (2008) Establishment of three fish cell lines and research on the sensitivity of twelve fish cell lines to heavy metal toxicity. Huazhong Agricultural University. https://kns.cnki.net/KCMS/detail/detail.aspx?dbname=CDFD0911\&filename=2008202932.nh

Tu ZG, Li HY, Zhang X, Sun Y, Zhou YC (2017) Complete genome sequence and comparative genomics of the golden pompano (Trachinotus ovatus) pathogen Vibrio harveyi strain QT520. PeerJ 5:e4127. https://doi.org/10.7717/peerj.4127

Wei S, Yu Y, Qin Q (2018) Establishment of a new fish cell line from the caudal fin of golden pompano, Trachinotus ovatus and its susceptibility to iridovirus. J Fish Biol 92:1675-1686. https://doi.org/10.1111/jfb.13566

Wen CM, Lee CW, Wang CS (2008). Development of two cell lines from Epinephelus coioides brain tissue for characterization of betanodavirus and megalocytivirus infectivity and propagation. Aquaculture 278:14-21. https://10.1016/j.aquaculture.2008.03.020

Wang L, Cao ZJ, Liu YX, Xiang YJ, Sun Y, Zhou YC, Wang SF, Guo WL (2020) Establishment and characterization of a new cell line from the muscle of humpback grouper (Cromileptes altivelis). Fish Physiol Biochem 46:1-11. https://doi.org/10.1007/s10695-020-00841-5

Wang L, Yan F, Chen GH, Luo J, Wu TC, Zou Y (2013) Study on the indoor pond seedling techniques of Cromileptes altivelis. Journal of Anhui Agri Sci 41(21):8909-8910,8913. https://doi.org/10.13989/j.cnki.0517-6611.2013.21.139

Wang XL, Wang N, Sha ZX, Chen SL (2010) Establishment, characterization of a new cell line from heart of half smooth tongue sole (Cynoglossus semilaevis). Fish Physiol Biochem 36:1181-1189. https://doi.org/10.1007/s10695-010-9396-5

Yu Y, Wei S, Wang Z, Huang X, Huang Y, Cai J, Li C, Qin Q (2016) Establishment of a new cell line from the snout tissue of golden pompano, Trachinotus ovatus, and its application in virus susceptibility. J Fish Biol 88:2251-2262. https://doi.org/10.1111/jfb.12986

Zhang SF, Dong HB, Wang Q, Zhang JS (2020) Effects of temperature on the growth oxygen consumption and thermal tolerance of young Cromileptes altivelis. Journal of Dalian Ocean University 36(1):74-79. https://doi.org/10.16535/j.cnki.dlhyxb.2019-332

Zhang MQ, Chen C, Li YL, Jia RJ, Yu H, Liang Y, Cai CY, Pang ZF (2014) Developmental and morphological characteristics of embryo, larval, juvenile, and young Fish, Chromileptes altivelis. Progress In Fishery Sciences 35(5):145-153. https://doi.org/10.11758/yykxjz.20140521

Zhou LL, Li PF, Liu JX, Ni SW, Yu YP, Yang M, Wei SN, Qin QW (2017) Establishment and characterization of a mid-kidney cell line derived from golden pompano Trachinotus ovatus, a new cell model for virus pathogenesis and toxicology studies. In Vitro Cell Dev-An 53:320-327. https://doi.org/10.1007/s11626-016-0112-3

Zhou JN, Su ML, Zhang JB (2019) Establishment and characterization of gill cell line from the spotted scat Scatophagus argus. J Trop Oceanogr 38(06):90-97. https://doi:10.11978/2019017 
Zheng Y, Wang N, Xie MS, Sha ZX, Chen SL (2012) Establishment and characterization of a new fish cell line from head kidney of half-smooth tongue sole (Cynoglossus semilaevis). Fish Physiol Biochem 38(6):1635-1643. https://doi.org/ 10.1007 / s10695-012-9660-y

\section{Figure Legends}

Fig. 1 Morphology of Cromileptes altivelis brain (CAB) cells at passage 1.

Fig. 2 CAB cells at $24 \mathrm{~h}$ after cell recovery at passage 8 (a) and confluent morphology of CAB cells at $72 \mathrm{~h}(\mathrm{~b})$

Fig. 3 PCR amplification of 18S rRNA gene of CAB cells (a) and the partial sequencing results of PCR product (b)

Fig. 4 The optimum growth conditions for CAB cells. (a) Effect of different FBS concentrations on the growth of CAB cells. $\boldsymbol{\square}, 20 \% ; \boldsymbol{\Delta}, 10 \% ; \bullet, 10 \% ; \times, 5 \%$. (b) Effect of different cell cultured medium on

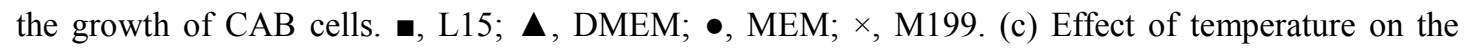
growth of CAB cell. $\mathbf{\square}, 28^{\circ} \mathrm{C} ; \boldsymbol{\Delta}, 26^{\circ} \mathrm{C} ; \bullet, 24{ }^{\circ} \mathrm{C} ; \times, 22^{\circ} \mathrm{C}$.

Fig. 5 Chromosome frequency distribution of CAB cells at passage 7 (a) and chromosome morphology of CAB cells (b)

Fig. 6 Analysis of DNA content of CAB cells at 24h (a) and 48 h (b). A: G0-G1 phase [(a) 69.13\%; (b) 82.90\%]; B: G2-M phase [(a) 3.34\%; (b) 4.82\%]; C: S phase [(a) 27.54\%; (b) 12.28\%]. (c) Quantification was expressed as the percentage of CAB cells in different phases of the cell cycle; $\mathbf{m}, 24$ h; $\square, 48$ h.

Fig. 7 Expression of enhanced green fluorescent protein (EGFP) in CAB cells at passage 12. (a) EGFP fluorescence in pEGFP-N3 transfected CAB cells. (b) Nucleus morphology of CAB cells stained by 6-diamidino-2-phenylindole (DAPI). (c) The merged images of EGFP and DAPI image.

Fig. 8 The susceptibility of CAB cells to bacteria. a-d, Cytopathic effect of CAB cells infected with PBS and Vibrio harveyi after $1 \mathrm{~h}$ and $3 \mathrm{~h}$ post-infection. $\mathrm{e}-\mathrm{h}$, Cytopathic effect of CAB cells infected with PBS and Edwardsiella tarda after $6 \mathrm{~h}$ and $9 \mathrm{~h}$ post-infection. (Scale bar=100 $\mu \mathrm{m})$

Fig. 9 Cytotoxicity analysis of three heavy metals $(\mathrm{Cd}, \mathrm{Hg}$ and $\mathrm{Cu})$ to $\mathrm{CAB}$ cells. Values are presented as the mean $\pm \mathrm{SD}$ of three independent experiments. $\mathrm{P}$ value $<0.05$ was considered statistically significant $(* \mathrm{P}<0.05 ; * * \mathrm{P}<0.01)$ 
Figure 1

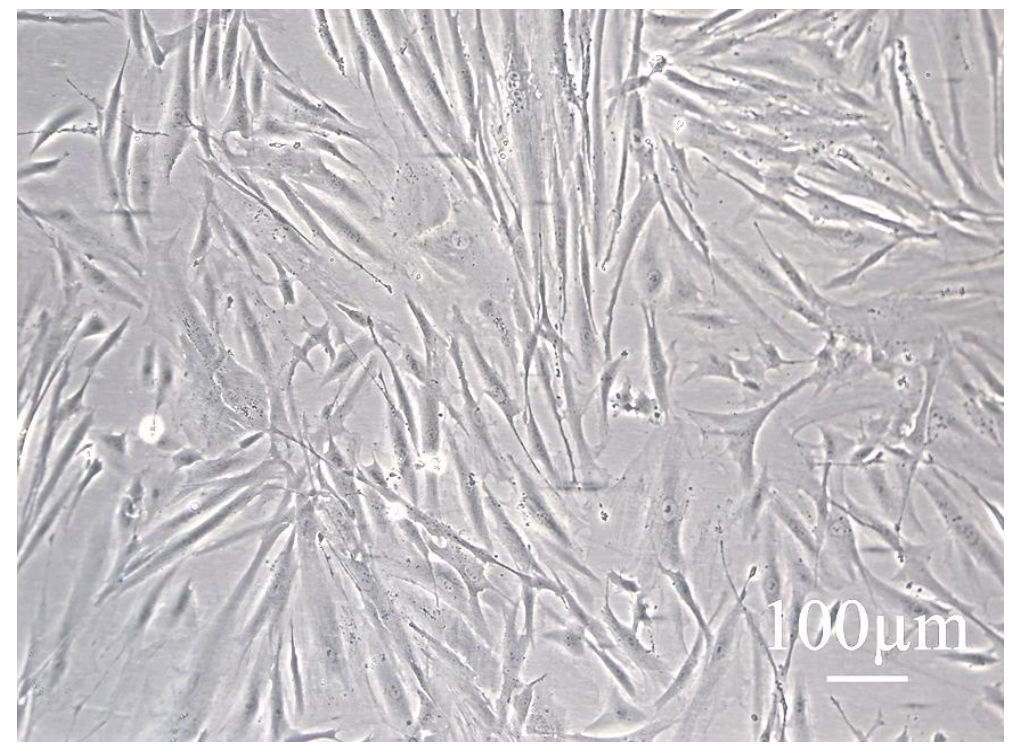

495

496

Figure 2

(a)

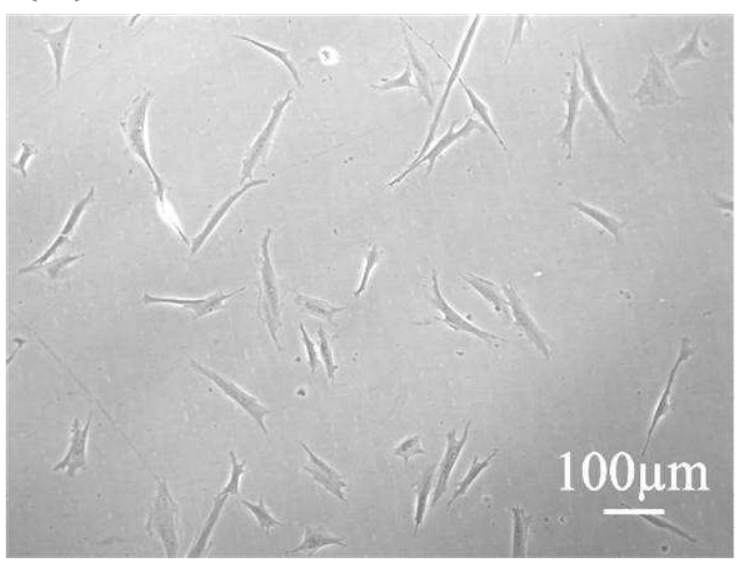

(b)

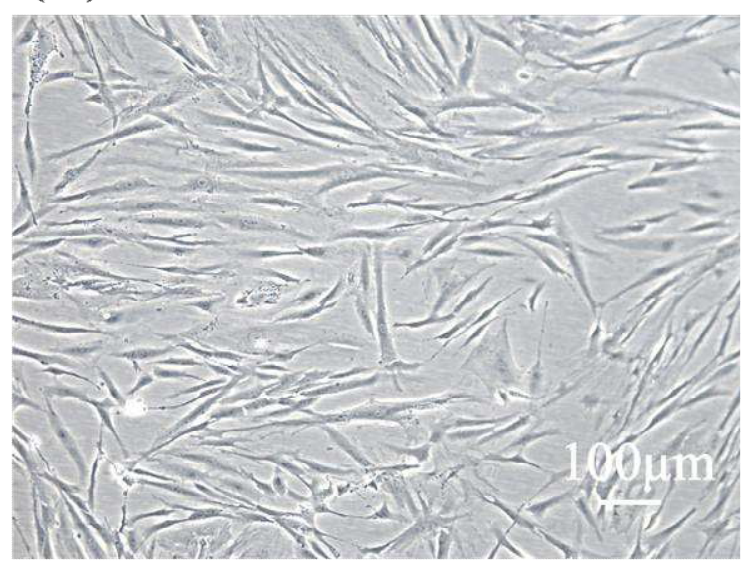




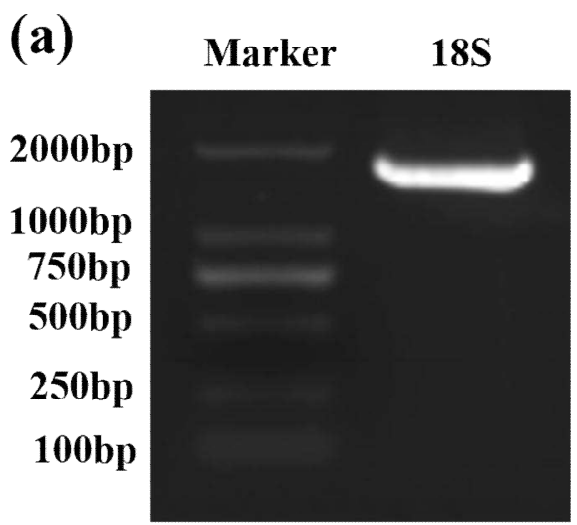

(b)

TACAGGACTCTTTCGAGGCCCTGTAATTGGAATGAGT ACACTTTAAATCCTTTAACGAGGATCAATTGGAGGGC AAGTCTGGTGCCAGCAGCCGCGGTAATTCCAGCTCCA ATAGCGTATCTTAAAGTTGCTGCAGTTAAAAAGCTCGT AGTTGGATCTCGGGATCGAGCTGACGGTCCGCCGCGA GGCGAGCTACCGTCTGTCCCAGCCCCTGCCTCTCGGC GCCCCCTCGATGCTCTTAGCTGAGTGTCCCGCGGGGT CCGAAGCGTTTACTTTGAAAAAATTAGAGTGTTCAAA GCAGGCCCGGTCGCCTGAATACCGCAGCTAGGAATAA TGGAATAGGACTCCGGTTCTATTTTGTGGGTTTTCTCT CTGAACTGGGGCCATGATTAAGAGGGACGGCCGGGG GCATTCGTATTGTGCCGCTAGAGGTGAAATTCTTGGAC 504 CGGCGCAAG

Figure 4
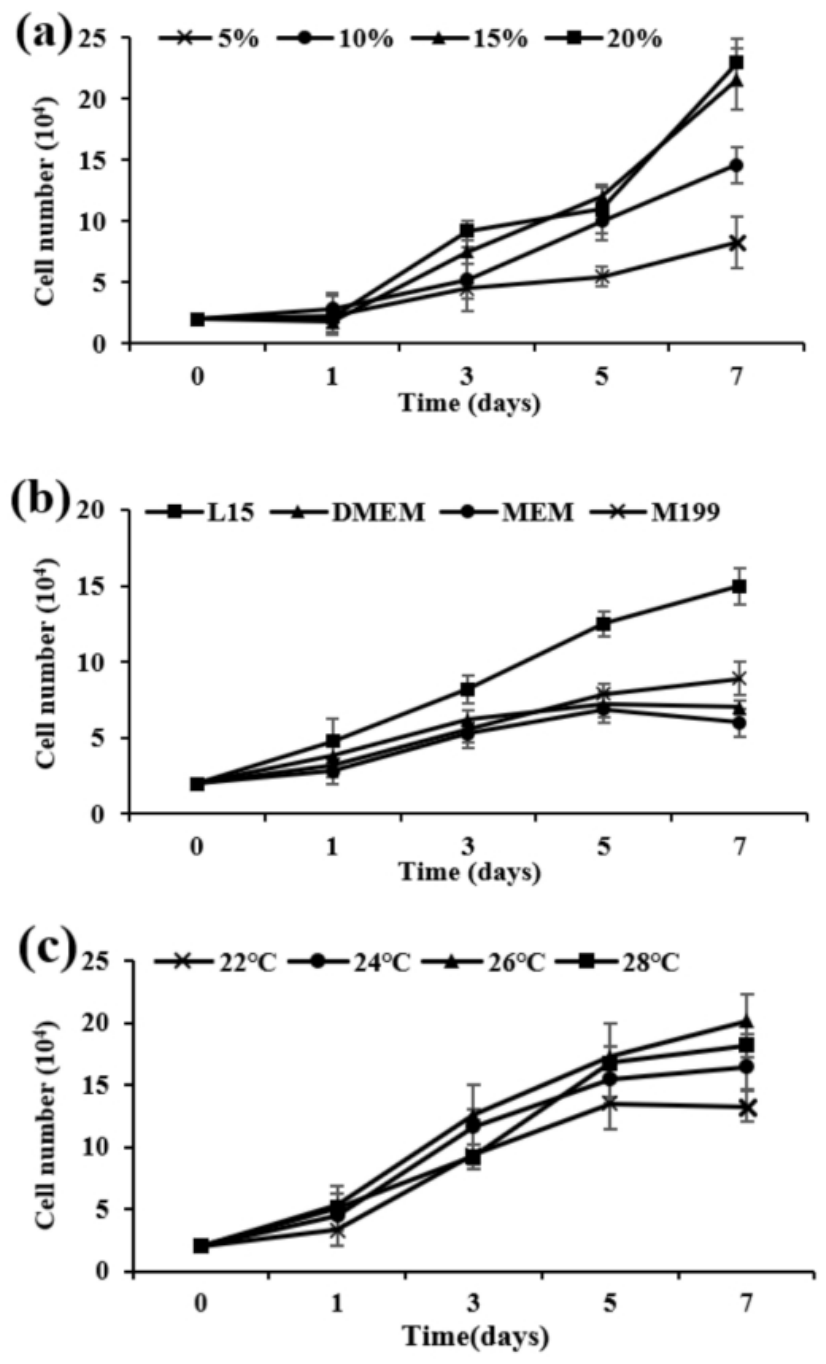
Figure 5

(a)

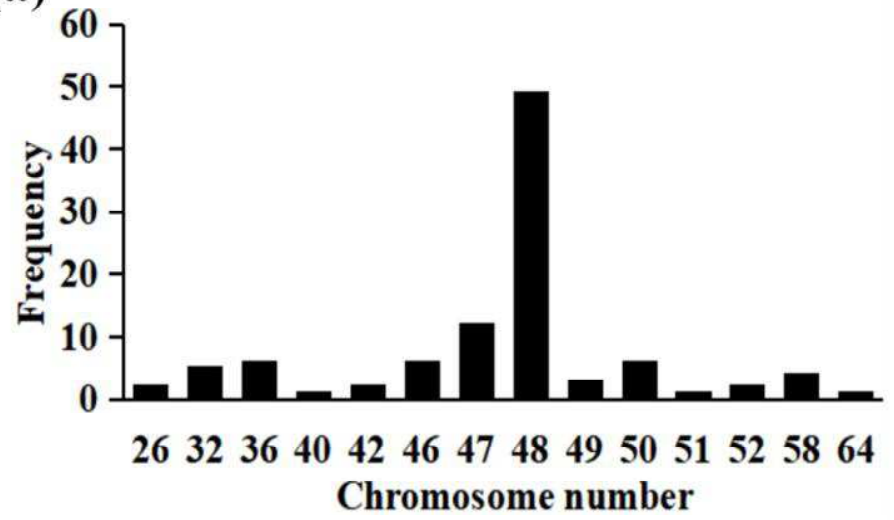

(b)

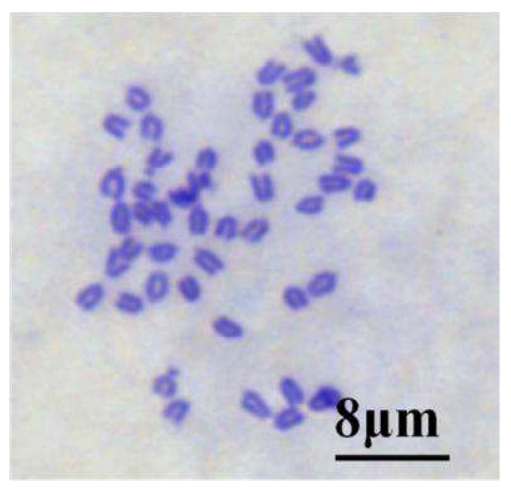

512

513

514

515

516

517

518

519

520

(a)

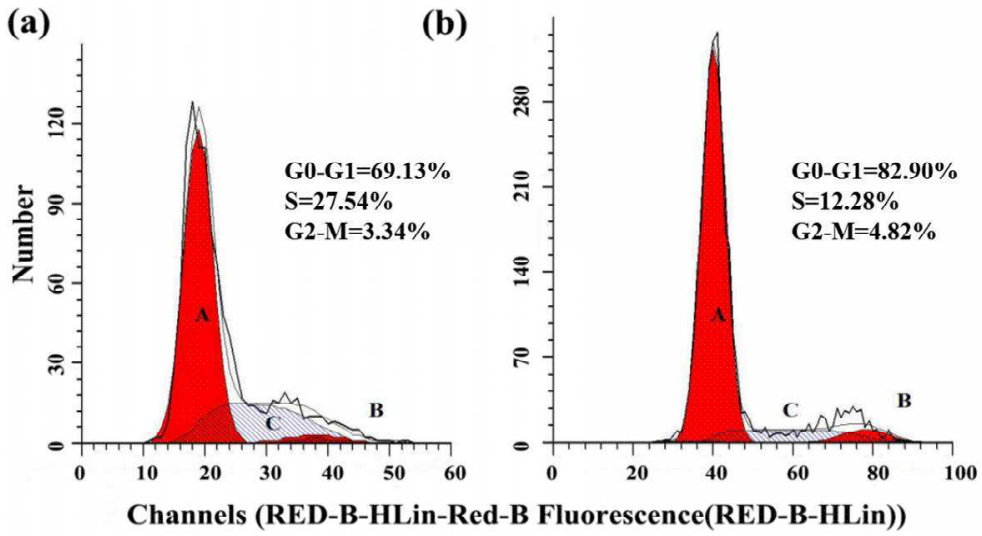

(c)

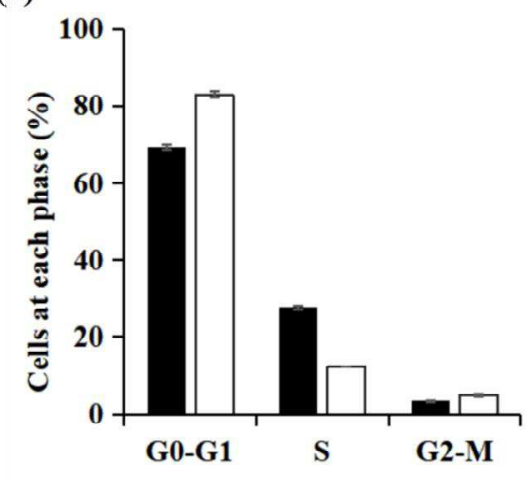


$524 \quad$ Figure 7

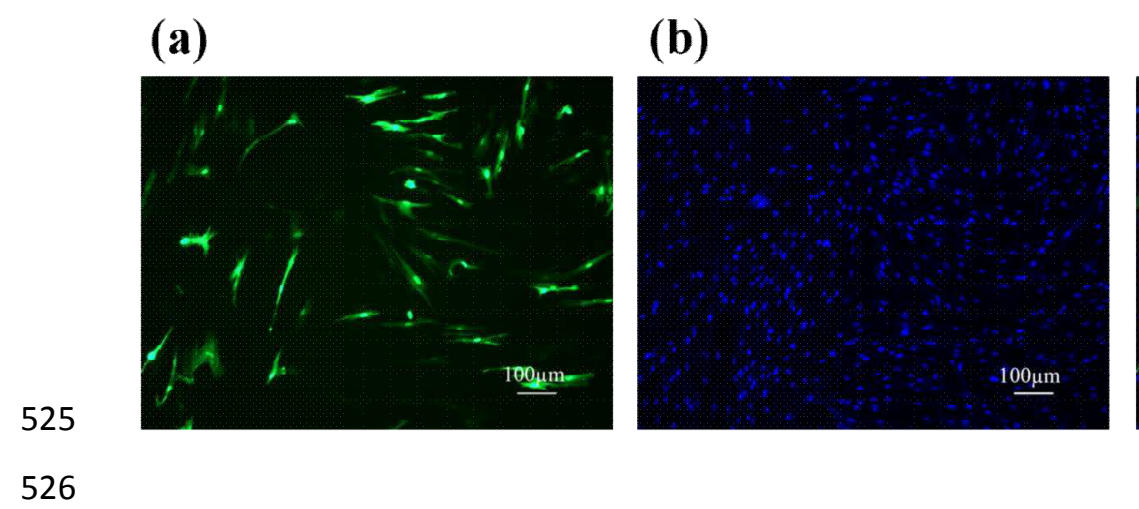

(c)

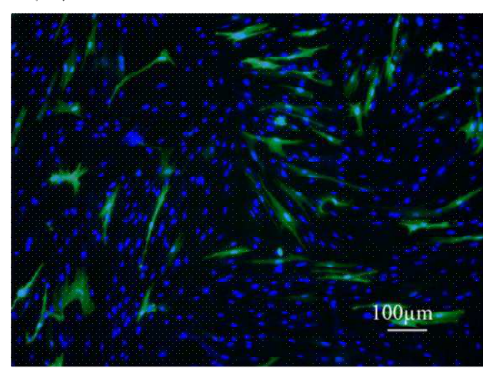

527

528

529

530

531

532

533

534

535

536

537

538

539

540

541 
(a) Control 1 hpi

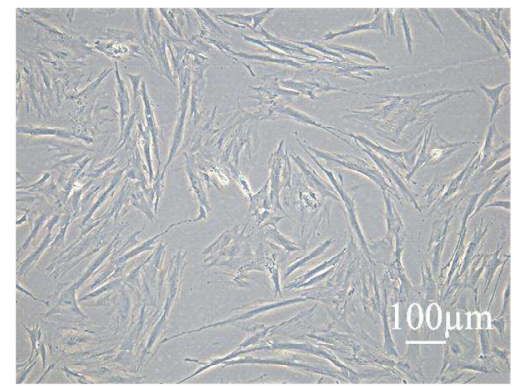

(c) Control 3 hpi

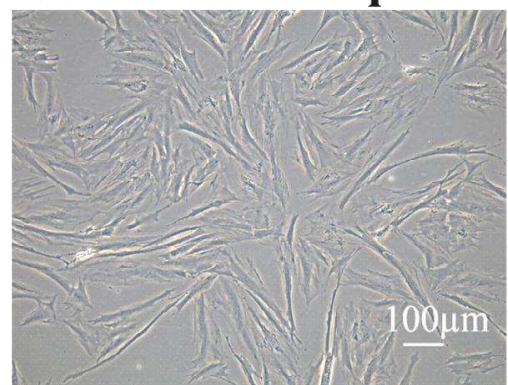

(e) Control $6 \mathrm{hpi}$

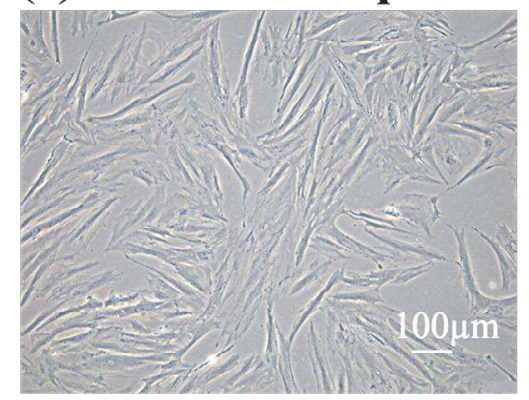

(g) Control 9 hpi

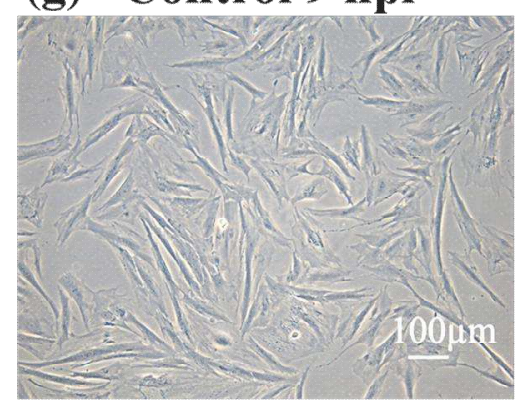

(b) V. harveyi 1 hpi

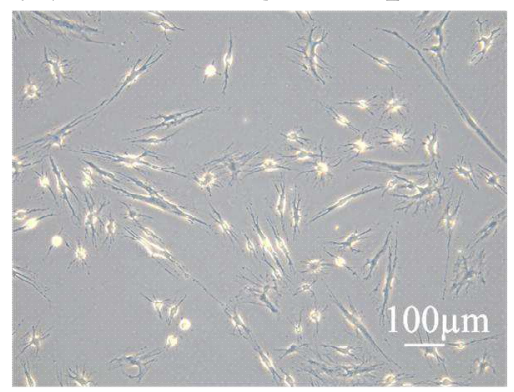

(d) V. harveyi 3 hpi

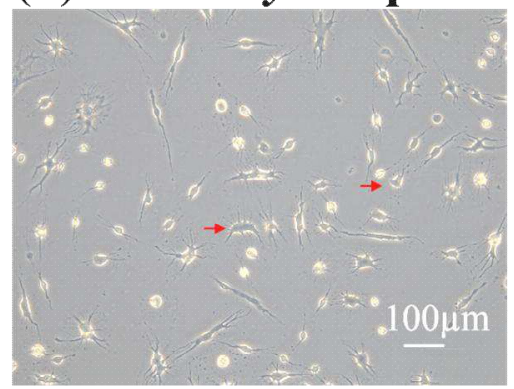

(f) E. tarda $6 \mathrm{hpi}$

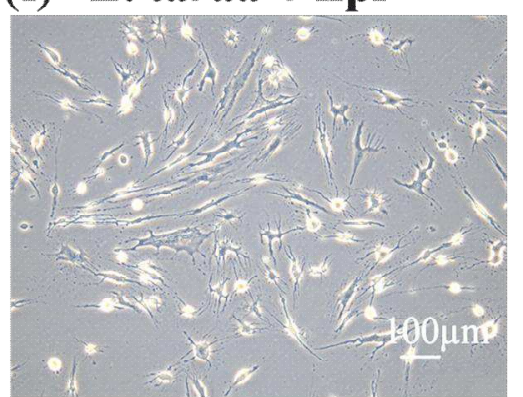

(h) E. tarda 9 hpi

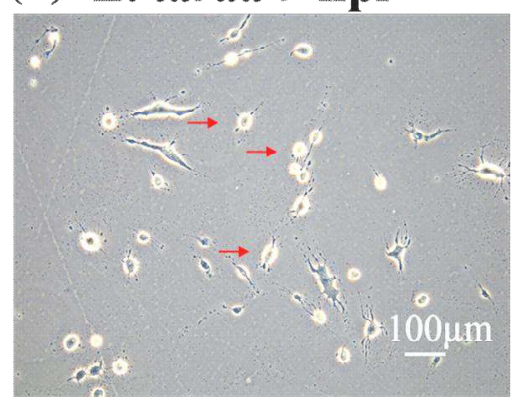


Figure 9
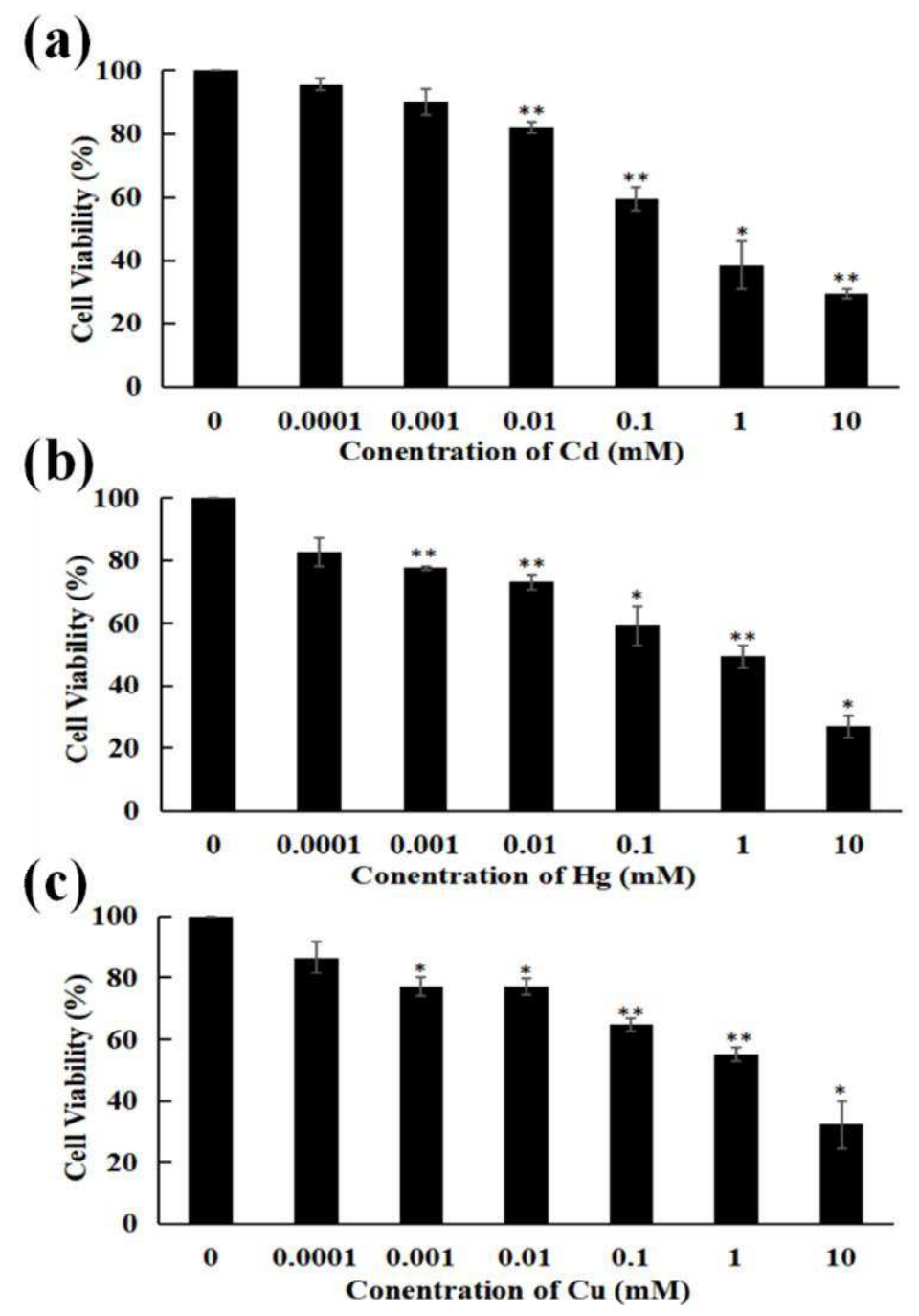

550 